砂質干潟におけるホトトギスガイの泥状のマット形成と基質攪拌による マット破壊が底生生物群集の季節変動に及ぼす影響

\title{
Influence of the Development and Destruction of Muddy Byssal Mats Made by a Mytilid Mussel, Musculista senhousia, on Seasonal Fluctuations of the Macrobenthic Community on Sandy Tidal Flats
}

\author{
堤 裕昭 $^{1)}$, * 野村龍之介 ${ }^{1 ）} \cdot$ 田上貴文 ${ }^{1)} \cdot$ 小森田智大 ${ }^{1 ）} \cdot$ 岩崎敏治 $^{2)} \cdot$ 藤森隆美 $^{3)}$ \\ 1) 熊本県立大学環境共生学部環境資源学科。 $\bar{T} 862-8502$ 熊本市月出 $3-1-100$ \\ 2）株式会社隆勢. $\bar{T} 861-6102$ 熊本県上天草市松島町合津 7915-12 \\ 3）川口漁業協同組合．８861-4123 熊本県熊本市川口町 3013-4
}

Hiroaki TSUTSUMI $^{1)}$,, Ryunosuke NOMURA ${ }^{1)}$, Takafumi TANOUE ${ }^{1)}$, Tomohiro KOMORITA $^{1)}$, Toshiharu IWASAKI ${ }^{1)}$ and Takami FUJIMORI ${ }^{1)}$

\footnotetext{
1) Faculty of Environmental and Symbiotic Sciences, Prefectural University of Kumamoto, 3-1-100 Tsukide, Kumamoto 8628502, Japan

2) Ryusei Co. Ltd., 7915-12 Aitsu, Matsushima, Kamiamakusa 861-6102, Japan

3) Kawaguchi Fishermen's Association, 3013-4 Kawaguchi, Kumamoto 861-4123, Japan
}

\begin{abstract}
On the Midori River Tidal Flats, which face Ariake Bay in Kumamoto, Kyushu, Japan, the originally sandy sediment has recently become widely covered with muddy byssal mats created by mytilid musseles, Musculista senhousia. Since the formally dominant bivalves in the macrobenthic community, such as Tapes (Ruditapes) philippinarum, Mactra veneriformis, and others, favor sandy sediment as their habitat, they have been excluded by the development of the muddy byssal mats. In this study, sediment covered such mats on the tidal flats was dug up to a depth of about $1 \mathrm{~m}$ with a power shovel fixed to a barge, with the aim of eliminating the muddy byssal mats, and restoring sandy surface sediment there. This operation was successful, and soon afterwards the two bivalves, $T$. (R.) philippinarum, and M. veneriformis, again became dominant in the macrobenthic community. The effect of digging up the sediment lasted through the year-long course of this study even though M. senhousia twice had a chance for dense recruitment of juveniles through reproduction.
\end{abstract}

Key Words: physical extirpation, Mactra veneriformis, Midori River Tidal Flats, muddy byssal mats, Musculista senhousia, sandy tidal flats, Tapes (Ruditapes) philippinarum

\section{はじめに}

九州西岸に位置する有明海は潮位の干満差が大潮時には 約 5〜 $6 \mathrm{~m}$ に達し, 干潮時には広大な干潟が現れ, その面 積は約 2 万 haにおよび, 日本の沿岸に現存する干潟総面 積の約 4 割を占める（環境庁 1994）。一般に，干潟では水 中で植物プランクトンが増殖するだけではなく, 基質表面 でも底生微細藻類が繁茂し, きわめて高い一次生産が生じ る（MacIntyre et al. 1996; Underwood \& Kromkamp 1999; 門 谷 2000; Montani et al. 2003). 福岡県南部〜熊本県北部の 有明海東岸には砂質干潟が広く分布し, 干潟の高い一次生

Received a March 2012 Accepted 3 December 2012

* Corresponding author

E-mail: capitella-hiro@dance.ocn.ne.jp
産に支えられて，アサリ（Tapes (Ruditapes) philippinarum)， ハマグリ（Meretrix lusoria），シオフキガイ（Mactra veneriformis), マテガイ (Solen macroceros) などの二枚貝類が 高密度に棲息して（池末 1980, 菅野 1981）, 漁業資源とし て利用されてきた (菊池 2000). そのなかでも, 熊本県荒 尾市〜熊本市の海岸の砂質干潟ではアサリの漁獲量が群を 抜いて大きく，1970年代には有明海における貝類の年間 総漁獲量が 10 万トンを超えていたが (菊池 2000), この 地域の砂質干潟だけで年間約 4 万〜 6 万 5 千トンを占めて いた（環境省 2006）。ところが，1980 年代になるとそのア サリの漁獲量が急激に減少し, 1997 年にはわずか 1,009 卜 ンまで落ち込んでしまい（Tsutsumi 2006），2000年代に なっても年間 5,000 トンに満たない漁獲量にとどまってい る（環境省 2006）。この期間中にアサリの棲息域となる砂 質干潟の面積にはほとんど変化がないことから，アサリの 棲息環境に何らかの変化が生じて稠密な個体群が崩壊して 
しまったことを示している。

このようなアサリの漁獲量の急激な減少は日本各地で発 生しているが, その原因としては, 高水温および低水温, 低塩分, 過剰の浮遊土, 溶存酸素の低下, 飼料不足, 過剩 の泥分, 底土の過剰な流動, 貝類へい死等による腐敗水, 有害プランクトン, 寄生虫, ホトトギスガイ (Musculista senhousia）やカキ等の動物群落やアオサ類やオゴノリ類等 の海藻群落による海底面被覆, ヒトデや巻貝類等などによ る食害, 外国産アサリ種苗との交雑による劣性の遺伝形質 出現, 重金属などの毒物, 漁具による傷害, ビブリオによ る疾病など, 様々な要因が挙げられている（柿野 2000; 松 川ら 2008).

有明海に面する熊本県の砂質干潟では総面積に大きな変 動はなく, 埋め立てなどによる環境の物理的攪乱は少ない. アサリの漁獲量が激減した原因としては, 梅雨期や台風の 来襲期の大雨によって山間部から大量の土砂が運ばれて堆 積すること（梶山ら 1983; 藤森ら 1983）, ナルトビエイ (Aetobatus flagellum), ツメタガイ (Glossaulax didyma), カ モ類等による食害などが原因として指摘されてきたが（中 原・那須 2002), 1970 年代以降のアサリ漁獲量の減少が 6 万トンを超えることを考慮すると，その原因についてはま だ未解明な部分が多く残されている。このようなアサリの 漁獲量激減の原因を解明する研究が進められる一方で, 熊 本市の緑川河口干潟や荒尾市の荒尾干潟では, アサリの漁 獲量の回復を目指して, 有明海の沖合の海底で採取された 海砂を用いて干潟の基質表面を覆い, 基質の物理化学的環 境を改変する実験が行われてきた。 その結果, 海砂で覆砂 した場所に限っては, アサリをはじめ, シオフキガイ, ホ トトギスガイ，マテガイなどの二枚貝類が高密度に棲息す るようになった（堤ら 2000, 2002; Yamaguchi et al. 2004）.こ の事実は, この地域の干潟におけるアサリの漁獲量を激減 させた主要な原因の 1 つが基質の物理化学的特性の変化に 由来することを示唆するとともに, 沖合の海底で採取され た海砂を用いた覆砂が二枚貝類を主体とする底生生物群集 を劇的に回復させる手段の 1 つとなりることを実証した.

ところが, 近年, 環境保護のために海砂や川砂の採取を 禁止する施策が全国に広まり, 九州の一級河川で川砂の採 取が 2000 年に原則禁止され (堤 2005), 熊本県内の海砂 の採取も制限されつつある. 今後, 干潟における底生生物 の回復を早めるためには覆砂を続ける余地が残っている が，覆砂用の砂を入手することが難しくなってきた。一 方, 近年, 覆砂によって二枚貝類の棲息量が回復した干潟 では，広範囲にわたってホトトギスガイが高密度に棲息す るようになった。この種は細い繊維質の足糸を分泌して他 の個体と結びつき, 泥の粒子をその足糸に絡みつかせるこ とにより，泥状のマットを形成して（伊藤・梶原 1981a， 1981b; Crooks 1998), 砂質干潟の基質表層を泥化させる. そのため, 砂質の基質を好むアサリ， シオフキガイ，マテ ガイなどの二枚貝類の棲息が再び難しくなっている.
そこで, 筆者らは, 熊本市の緑川河口干潟において, 基 質表層が中砂を主体とした砂質干潟として元来の粒度組成 に戻り，アサリやシオフキガイなどの二枚貝類が優占する 底生生物群集を回復させることをめざして，2010 年 7 月 にホトトギスガイが高密度に棲息して厚い泥状のマットを 形成する場所の基質を重機で攪拌し，その泥状のマットを 破壊し，基質表層をそのマットの下にある砂質の層と置換 する実験を行った。本論文では，緑川河口干潟の下部にお ける 2008 年〜2009 年の底生生物群集の季節変動に関する 定量調査の結果を報告し，ホトトギスガイの生息密度の急 速な増加と泥状のマット形成に伴う基質の粒度組成の変化 を示す。ならびに，この調査域に隣接した場所で 2010 年 7 月に実施した，ホトトギスガイが泥状のマットを形成し た基質を重機で攪拌する実験の結果を報告し，この方法が アサリやシオフキガイなどの砂質の基質に棲息する二枚貝 類の回復をめざした対策として有効であるかを検証すると ともに，ホトトギスガイによる泥状のマット形成と基質の 物理的な攪乱がこれらの二枚貝類の棲息におよぼす影響に ついて考察する.

\section{方法および材料}

\section{調査地}

本研究においては, 熊本県熊本市の緑川河口干潟下部の アサリ漁場として利用されてきた場所の一画に，底生生物 群集の季節変動ならびに基質の粒度組成の季節変化を調査 する地点として, Stn L $\left(32^{\circ} 43^{\prime} 39^{\prime \prime} \mathrm{N}, 130^{\circ} 34^{\prime} 24^{\prime \prime}\right.$ E, Fig. 1) を 設定した。また, この調査地点南西側に隣接して, 約 $100 \mathrm{~m}$ 四方の基質擋拌のための実験区を設定し（32 ${ }^{\circ} 43^{\prime} 6.3^{\prime \prime} \mathrm{N}, 130^{\circ}$ 33'58.2"E, Fig. 1)，この実験区を 4 分割して，それぞれの 区画に 1 地点ずつ計 4 調査地点を設けた（Stn Ex. 1〜 Stn Ex. 4).この実験区では, 実験開始前の 2010 年 7 月には, Stn Ex. 1〜Stn Ex. 3 を含む面積約 3/4 の場所の基質表面が ホトトギスガイの作った泥状のマットに覆われていた (Fig. 1 に示す Experimental site において灰色で示された区 域). 実験区に近接して，ホトトギスガイの泥状のマット で表層が厚く覆われていて，基質の攪拌を行わなかった場 所を対照地点として Stn C を設けた.

\section{底生生物群集の季節変動ならびに基質の粒度組成の季節変 化に関する調查}

2008 年 3 月〜 2009 年 9 月に, Stn L において, 毎月 1 回 大潮干潮時に，底生生物の定量調査および基質の粒度組成 に関する調査を行った。底生生物の定量調査で, 方形コア サンプラー $(10 \times 10 \times 5 \mathrm{~cm})$ を用いて 10 回基質を採取し， それぞれ目合い $1 \mathrm{~mm}$ の篩でろるい，ふるい上の残差物を サンプルとした。 また，基質の粒度組成を分析するため に，方形コアサンプラー $(5 \times 5 \times 5 \mathrm{~cm})$ を用いて 1 回基質 を採取した。 


\section{Midori River Tidal Flats}

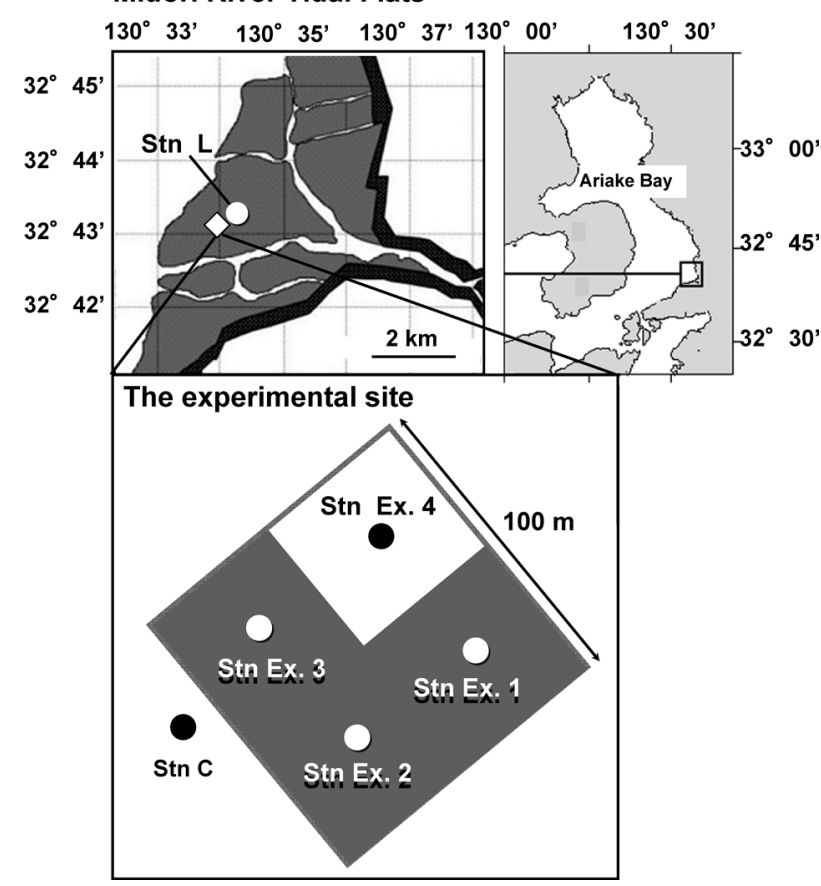

Fig. 1. Study area, Midori River Tidal Flats in Kumamoto, Kyushu, Japan. The gray-shaded areas in the experimental site were covered by byssal mats of Musculista senhousia, with much ambient muddy sediment, at the start of this study in July, 2010.

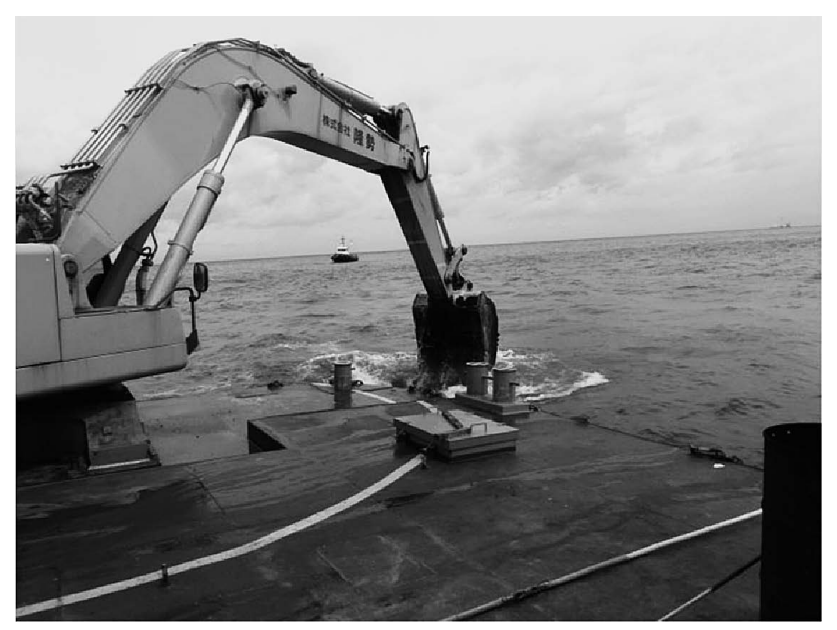

Fig. 2. Operations to dig up the sediment on the tidal flats using a power shovel fixed to a barge.

\section{基質の擋找実験と調査}

2010 年 7 月 11 日, 実験区の全域（約 $100 \mathrm{~m}$ 四方）にお いて, 株式会社隆勢所有の重機（KOMATSU, PC800）を 用いて, 深さ $1 \mathrm{~m}$ 程度まで基質を掘り起こして, 攪挥し た（Fig. 2). 基質の擋找を行う直前の 2010 年 7 月 11 日お よび擋拌後の 9 月 8 日に, 実験区の 4 調査地点（Stn Ex. 1 〜Stn Ex. 4）において，干潮時に柱状コアサンプラー（内 径 $4 \mathrm{~cm}$, 長さ $45 \mathrm{~cm}$ ）を用いて表層より深さ $20 \mathrm{~cm}$ （Stn Ex. 1 のみ深さ $30 \mathrm{~cm}$ ）までの基質コアサンプルを採取し, 深さ $1 \mathrm{~cm}$ 層ごとに切り分けた。また，2010年 7 月〜2011
年 9 月に, 2011 年 2 月を除き毎月 1 回, 大潮干潮時に実 験区の 4 調査地点ならびに $\operatorname{Stn} C$ において, 基質の粒度組 成の調查および底生生物の定量調查を行った。なお, Stn $\mathrm{C}$ においては, 2010 年 9 月および 10 月には干出時間が短 く調査ができなかった. 各調査地点において, 基質の粒度 組成の調査では，方形コアサンプラー $(5 \times 5 \times 5 \mathrm{~cm})$ を用 いて基質サンプルを 1 回採取した。底生生物の定量調査で は, 方形コアサンプラー $(10 \times 10 \times 5 \mathrm{~cm})$ を用いて基質を 5 回採取し, 目合い $1 \mathrm{~mm}$ 目の篩を用いてふるい, ろるい 上の残渣物をサンプルとした。

\section{分析方法}

方形コアサンプラーを用いて採取した基質サンプルは, ウエットシービング法によって粒度組成の分析を行った。 柱状コアサンプラー用いて採取した基質サンプルは, 鹿児 島大学総合博物館において, レーザー回折式粒度分布測定 装置（SHIMADZU, SALD-3100）を用いて各層別に詳細な 粒度分析を行い，基質の含泥率および中央粒径值を求め た。底生生物の定量調查用サンプルは，ローズベンガルを 溶かしたホルマリン $10 \%$ 溶液を用いて固定と染色を行い, プラスティック・バッグに保管した，後日，ホルマリン固 定したサンプルを目合い $1 \mathrm{~mm}$ の篩を用いて再度ふるいな がら水洗した，実体顕微鏡下でろるいの残椬物中の底生生 物をすべて選りだし, 種を同定し, 各種別に個体数の計数 ならびに湿重量の計測を行った。

\section{結果}

\section{底生生物群集におけるホトトキスガイの卓越と基質の粒度 組成の変化}

Fig. 3 には, Stn L における底生生物群集の密度および湿 重量の 2008 年 3 月〜 2009 年 10 月の変化を示す. 2008 年 3 月には，アサリが密度および湿重量ともに底生生物群集の 最優占種を占め, それぞれ2,070 ind. $\mathrm{m}^{-2}$ および $6,122 \mathrm{gWW} \mathrm{m}^{-2}$ に達していた。ホトトギスガイは 2008 年 8 月に大量の稚貝の新規加入が確認された $\left(16,570\right.$ ind. $\left.\mathrm{m}^{-2}\right)$. 同種は, 11 月〜 12 月にも稚貝の新規加入が見られ，それ に対応した密度の増加が 2009 年 1 月にわずかに認められた $\left(10,980\right.$ ind. $\left.\mathrm{m}^{-2}\right)$ ． ホトトギスガイの密度は，その後 2009 年 3 月〜2010 年 10 月には 4,940 8,360 ind. $\mathrm{m}^{-2}$ を保った. これらの個体の成長に伴い, 湿重量は徐々に増加し, 2009 年 3 月には $1,770 \mathrm{gWW} \mathrm{m}^{-2}$, 同年 9 月には $4,972 \mathrm{gWW} \mathrm{m}^{-2}$ に達した。これに対して，アサリは2008 年 8 月まで密度 で 1,630 ind. $\mathrm{m}^{-2}$, 湿重量で $1,716 \mathrm{gWW} \mathrm{m}^{-2}$ を保っていた が, ホトトギスガイの密度の増加に伴って減少し, 2009 年 10 月には密度がわずか 90 ind. $\mathrm{m}^{-2}$, 湿重量も 56.0 $\mathrm{gWW} \mathrm{m}^{-2}$ まで低下した。密度は 2009 年 5 月〜 6 月に一旦 1,560 1,660 ind. $\mathrm{m}^{-2}$ に回復したが，これは湿重量の増加 を伴っていないので, 稚貝の新規加入によるものと考えら 
(a)

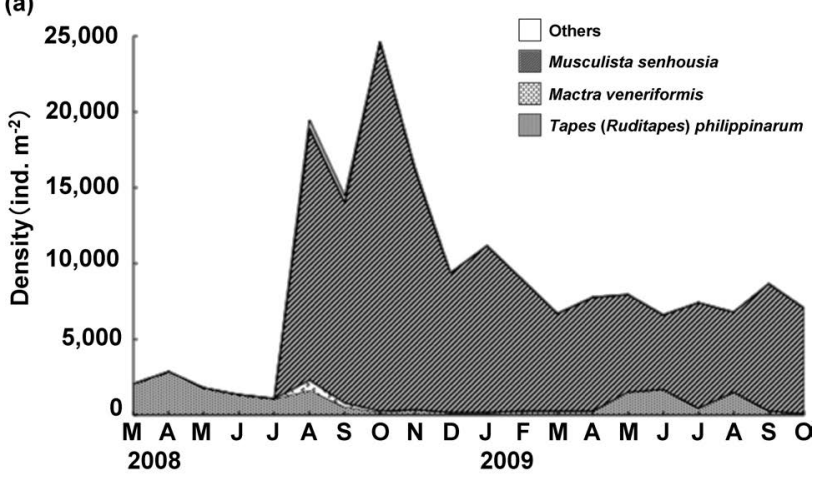

(b)

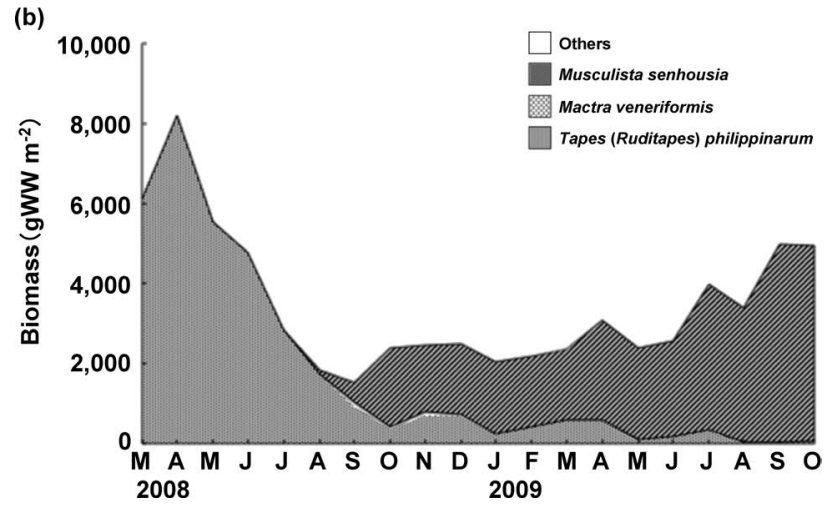

Fig. 3. Seasonal changes of (a) densities and (b) biomass in wet weight of the macrobenthic communities at Stn L on Midori River Tidal Flats between March, 2008, and October, 2009.

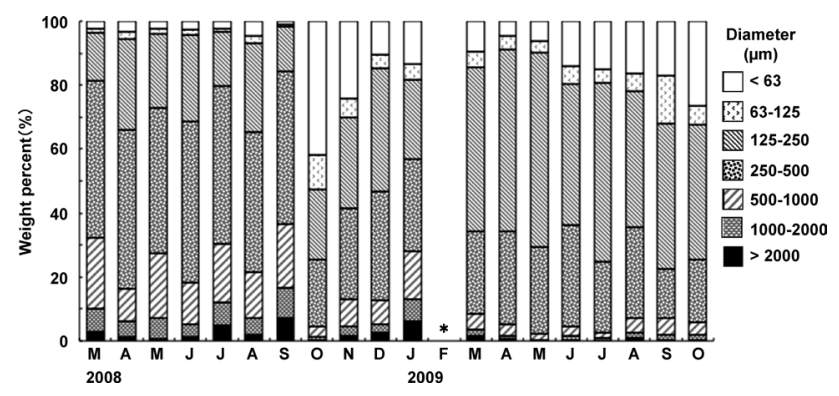

Fig. 4. Seasonal changes of the particle size composition of the sediment at Stn L on Midori River Tidal Flats between March, 2008, and October, 2009.
れる。これらの個体も 9 月までにはほとんど棲息しない状 態となり，2009年 9 月〜 10 月にはホトトギスガイが独占 的に棲息する状態となった。

Fig. 4 には, Stn L における 2008 年 3 月〜2009年 10 月 の基質の粒度組成の変化を示す。 2008 年 3 月～9 月の基質 の泥分（粒径 $63 \mu \mathrm{m}$ 未満）はわずか $2.5 \pm 1.2 \%$ (平均值士 標準偏差）で，中砂（粒径 250～500 $\mu \mathrm{m}, 47.9 \pm 2.5 \%$ ）お

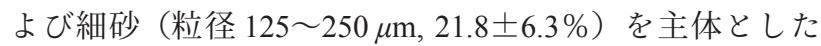
砂質の基質が存在していた。ところが，ホトトギスガイが 2008 年 8 月に高密度個体群 (16,570 ind. $\mathrm{m}^{-2}$ ) を形成し, それらの個体の成長によって個体群の湿重量が 10 月に $1,973 \mathrm{gWW} \mathrm{m}^{-2}$ に達すると, 基質の粒度組成が一変して, 泥分（粒径 $63 \mu \mathrm{m}$ 未満）が $41.9 \%$ に増加した。この泥分 は冬季から翌年の春季にかけて徐々に減少したが，2009 年 4 月の $4.1 \%$ を最小值として，その後は再び増加して 10 月には $26.5 \%$ に達した。また，2008 年 10 月以降は，極細 砂（粒径 63〜125 $\mu \mathrm{m}$ ）および細砂の比率も増加し, 泥, 極細砂, 細砂の 3 つの成分の比率の合計值は 2009 年 10 月 まで $42.0 \%$ 77.5\%を占めた. Fig. 5 には 2009 年 9 月の Stn L の基質表層の写真を示す。基質表層はホトトギスガ イが分泌した足糸に泥や極細砂が付着して形成された泥状 のマットで覆われ，内部は嫌気化していた。

\section{重機を用いた基質の擋找による粒度組成の变化}

Fig. 6 には重機を用いて基質を擋挥した実験区における 攪拌直前（2010 年 7 月 11 日）および攪拌後（2010 年 9 月 8 日）の基質表面の写真を，Fig. 7 には実験区の 4 地点 （Stn Ex. 1〜Stn Ex. 4）における基質各層の泥分および中央 粒径值の平均值の鉛直プロファイルを示す．基質の擋拌直 前には，基質はホトトギスガイが形成した泥状のマットに 覆われていた（Fig. 6(a)). 基質の泥分は，深さ $5 \mathrm{~cm}$ まで の層で $6.7 \pm 3.0 \%$ (平均值士標準偏差), 深さ 5〜 $10 \mathrm{~cm}$ 層 で $13.5 \pm 5.5 \%$, 深さ $10 \sim 15 \mathrm{~cm}$ 層で $19.0 \pm 6.8 \%$, 深さ 15 〜20 cm 層では $23.4 \pm 10.9 \%$ と徐々に増加した．泥分の最

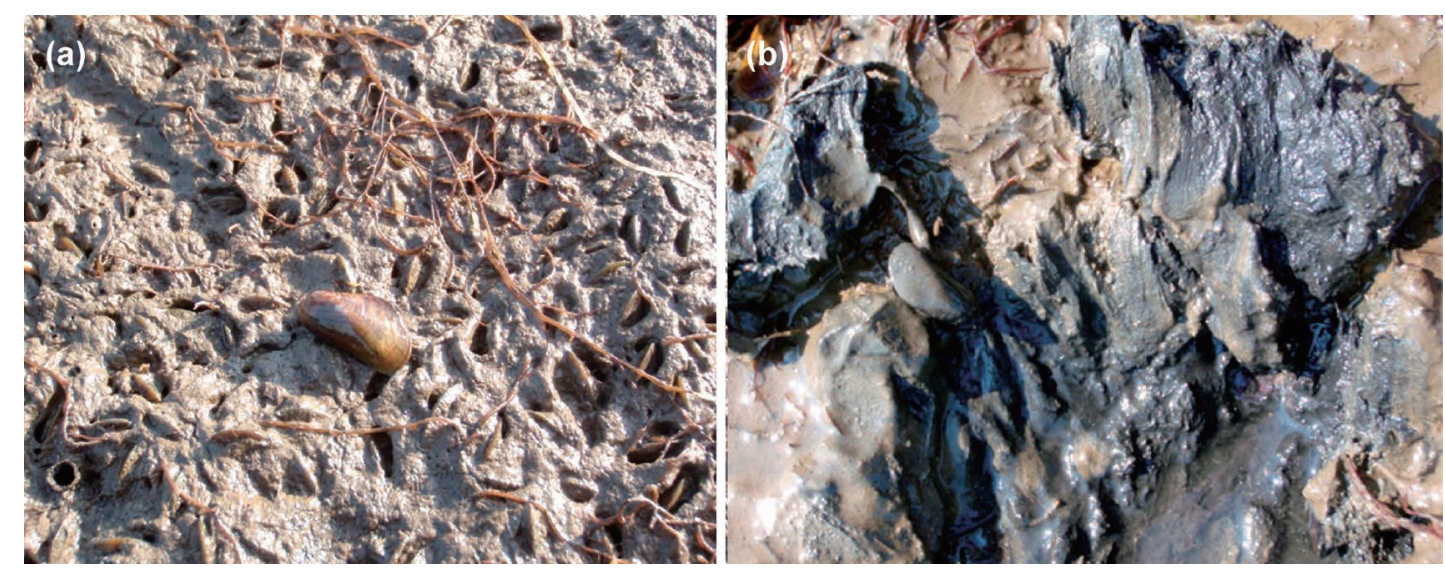

Fig. 5. (a) Sediment top (a) and beneath (b) the byssal mats created by Musculista senhousia, showing highly reduced conditions in the mats. These photos were taken at Stn L on Midori River Tidal Flats on September 18, 2009. 

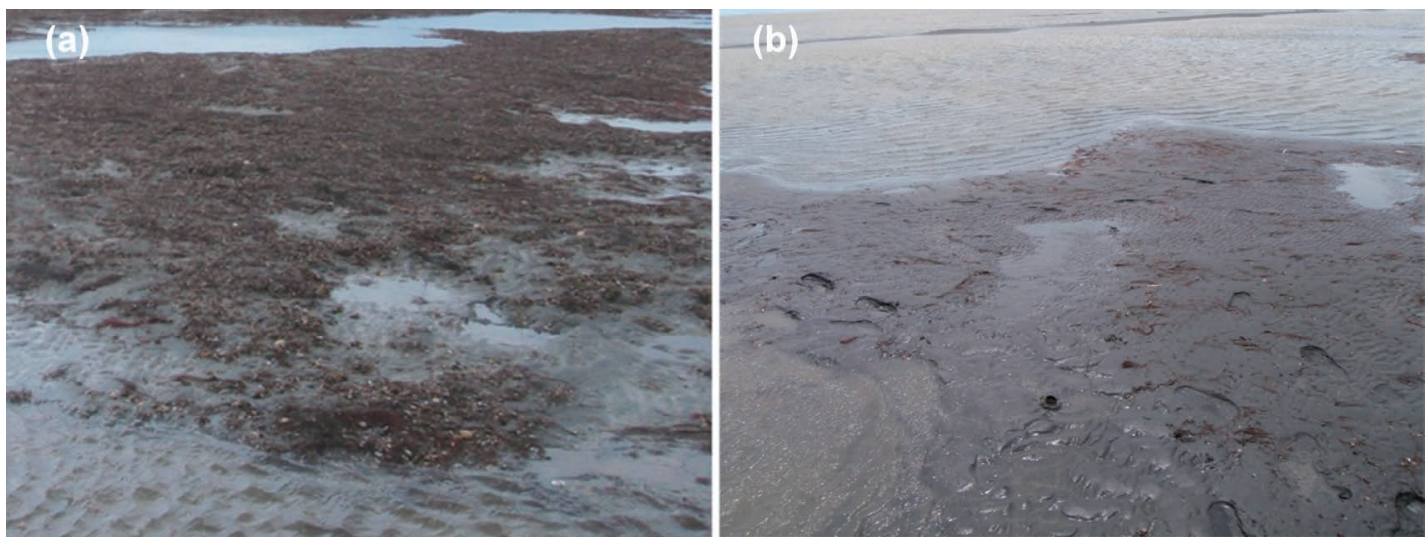

Fig. 6. Sediment surface at the experimental site on Midori River Tidal Flats (a) before and (b) after digging. These photos were taken on July 11 and September 8, 2010, respectively.
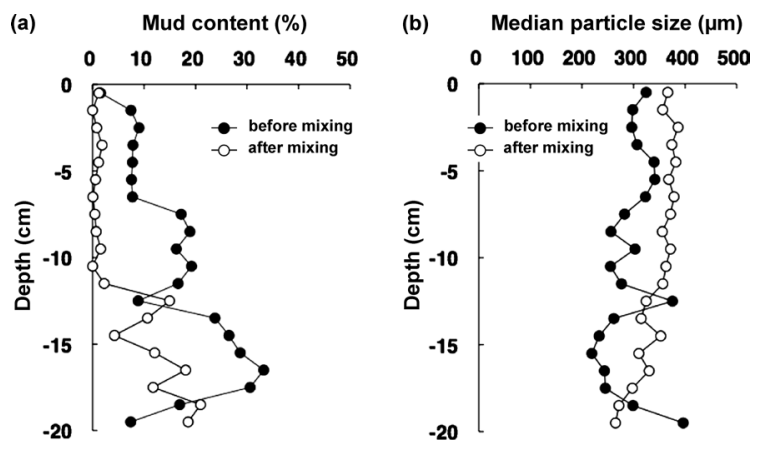

Fig. 7. Vertical profiles of (a) mud content and (b) median particle size of the sediment before and after digging operations on Midori River Tidal Flats.

高值は深さ $16 \sim 17 \mathrm{~cm}$ 層で $33.2 \%$ を記録した。それより深 層では泥分は急激に減少し, 深さ $19 \sim 20 \mathrm{~cm}$ 層では泥分は 7.4\%まで低下した．Stn Ex. 1 においては，さらに深さ $30 \mathrm{~cm}$ までの層の基質を採取することができたが，深さ 22 〜 $24 \mathrm{~cm}$ 層の泥分は $11.9 \%$ に対して, 深さ $24 \sim 30 \mathrm{~cm}$ 層で は $0.0 \sim 3.4 \%$ に低下し，砂質の層となった．以上のよう に, ホトトギスガイによって形成された泥状のマットは, 深さ $20 \mathrm{~cm}$ 前後に達していた。

重機を用いた基質の攪拌後には，このホトトギスガイが 形成した泥状のマットは基質表層から消失し, 砂質の基質 に変化していた（Fig. 6(b)). 深さ $12 \mathrm{~cm}$ までの層ではほ とんど泥が含まれない状態となり（泥分： $0.9 \pm 0.7 \%$, 平 均值士標準偏差), 基質の攪挥直前の泥分と統計学的にも 有意な差が認められた $(t$-test, $t=6.207, p<0.01)$. 深さ 12 $\mathrm{cm}$ より深い層では基質の擋拌直前と同様に泥分の増加傾 向が見られたが，深さ 12〜18 cm の層の泥分は $8.7 \pm 4.6 \%$ で，基質の擋拌直前 $(25.3 \pm 12.0 \%)$ と比較すれば，この 層でも大幅に泥分が減少した（ $t$-test, $t=3.257, p<0.05)$.

基質の中央粒径值にも大きな変化が認められた．基質の 攪找直前の深さ $5 \mathrm{~cm}$ までの層の 4 地点 (Stn Ex. 1 Stn Ex. 4）の中央粒径值は $313.2 \pm 18.5 \mu \mathrm{m}$ （平均值士標準偏 差), 深さ 5 10 cm 層では $301.2 \pm 33.4 \mu \mathrm{m}, 10 \sim 15 \mathrm{~cm}$ 層

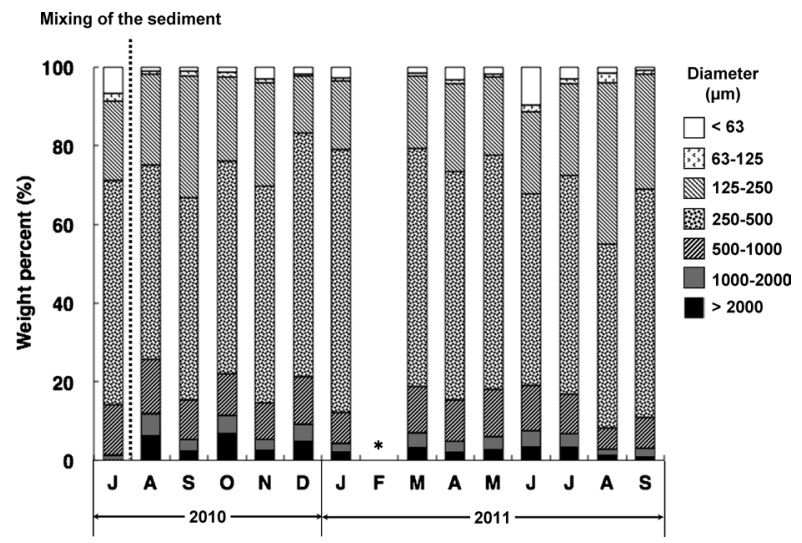

Fig. 8. Seasonal changes of the particle size composition of the sediment at the experimental site (the mean values of the four experimental stations, Stn Ex. 1 to Stn Ex. 4) on Midori River Tidal Flats between July, 2010, and September, 2011.

では $280.5 \pm 55.3 \mu \mathrm{m}$ ，媣さ $15 \sim 20 \mathrm{~cm}$ 層では $280.6 \pm 70.9 \mu \mathrm{m}$ であった．基質の攪拌後は，深さ $12 \sim 13 \mathrm{~cm}$ 層を除いて, 深さ $18 \mathrm{~cm}$ までのすべての層で中央粒径值が増加した（中央 粒径值の平均值： $355.1 \pm 26.3 \mu \mathrm{m}$, 増加分： $65.5 \pm 38.3 \mu \mathrm{m}$ ).

\section{重機を用いた基質の擋拌後の粒度組成の変化}

Fig. 8 には, 2010 年 7 月〜2011 年 9 月における実験区 の 4 地点（Stn Ex. 1 S Stn Ex. 4）の表層（深さ $5 \mathrm{~cm}$ までの 層）の粒度組成の平均值を示す. 基質の攪拌直前の 2010 年 7 月における基質表層の粒度組成の特徵としては, 泥分 が 6.6\%に達していたこと, 中砂がもっとも高い比率 （57.1\%）を占め, 次いで細砂が $20.2 \%$ を占めていたこと である. 重機を用いた基質の攪拌後の 2010 年 8 月の基質 では, 中砂および細砂主体の粒度組成に大きな変化は見ら れなかったが (中砂 : 49.3\%, 細砂 : 23.1\%), 泥分はわず か $1.0 \%$ に低下し，7月にはほとんど含まれなかった砂 （粒径 $2 \mathrm{~mm}$ 以上）および極粗砂（粒径 1〜2 $\mathrm{mm}$ ）がそれ ぞれ $6.3 \%$ および $5.7 \%$ に増加した。

2010 年 9 月以降も, 基質の粒度組成は中砂および細砂 
がそれぞれ $56.4 \pm 5.7 \%$ および $23.9 \pm 7.3 \%$ を占める構造が 続き, 泥分も 2011 年 6 月を除き, $2.0 \pm 0.9 \%$ の低い範囲を 推移した. 2011 年 6 月には, 泥分が一時的に $9.6 \%$ に増加 したが，7月には $3.0 \% ， 8$ 月には $1.8 \%$ に低下した。これ は梅雨期の大雨で川を通して土砂が流入して堆積したため と考えられるが, この泥は梅雨期終了後には水中に再懸濁 し，泥分はすぐに低下した。

\section{底生生物群集の密度と湿重量}

基質の擋拌直前（2010 年 7 月 11 日）ならびに擋拌後の 2010 年 8 月～2011 年 9 月における実験区（Stn Ex. 1 Stn Ex. 4）および対照地点の Stn C の底生生物群集の密度およ び湿重量の変化について，それぞれ Fig. 9 および Fig. 10 に示す.なお, 実験区の 4 調査地点（Stn Ex. 1～Stn Ex. 4） については平均值を示す.

Stn Cでは, 調査期間を通して基質表層にホトトギスガ イの泥状のマットが形成されていた。同種は底生生物群集 の最優占種であり, 2010 年 7 月に密度は 800 ind. $\mathrm{m}^{-2}$ に とどまっていたが, 湿重量は $912.5 \mathrm{gww} \mathrm{m}^{-2}$ に達してい た. 8 月には逆に密度が 18,925 ind. $\mathrm{m}^{-2}$ に急増したが, 湿 重量はわずか $30.9 \mathrm{gww} \mathrm{m}^{-2}$ に激減した。これはホトトギ スガイが 7 月頃に繁殖した後, 個体群の大部分の個体が死 亡したことと, 続いて大量の稚貝が新規加入した結果で あった。ホトトギスガイの密度は 2010 年 11 月に 2,100 ind. $\mathrm{m}^{-2}$ に一旦減少した後, 徐々に増加して, 2011 年 6 月 には 8,800 ind. $\mathrm{m}^{-2}$ に達した. 湿重量も同期間に 319.5

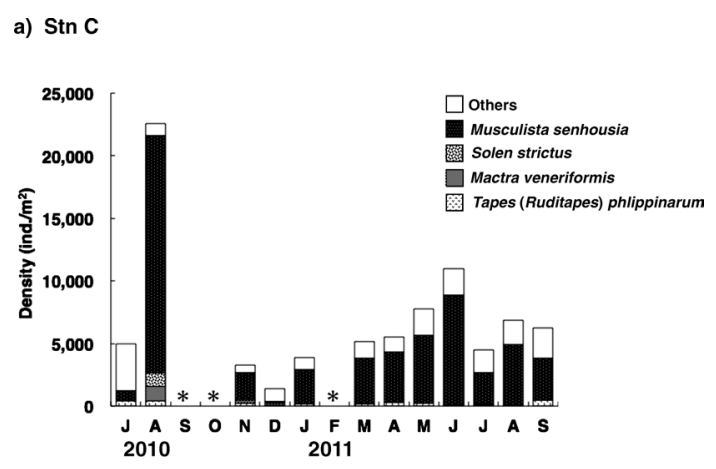

b) Experimental Stations (Stn Ex. 1 to Ex. 4)

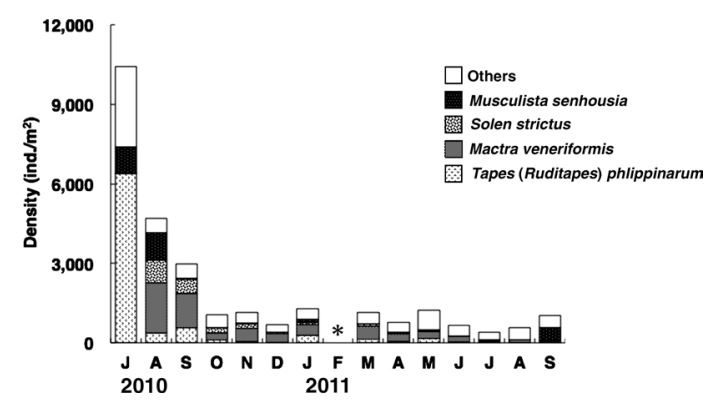

Fig. 9. Seasonal changes of the densities of macrobenthic communities at (a) Stn C, and (b) the experimental site (the mean values of the four experimental stations, Stn Ex. 1 to Stn Ex. 4). gww m ${ }^{-2}$ から 2,699.2 $\mathrm{gww} \mathrm{m}^{-2}$ に増加した. 採集した底生 生物の定量サンプルの観察からは, 12 月頃に再び新規加 入による稚貝の定着が見られた。この調査域では, ホトト ギスガイは個体群として年に 2 回繁殖していると考えられ る. 12 月頃に新規加入した個体は冬季の低水温のために 成長速度が遅く, 本研究で基質をろるった目合い $1 \mathrm{~mm} の$ ふるいには春季の成長によって残るようになり, 密度が 2011 年 6 月にむけて増加したと考えられる.この地点で は, ホトトギスガイの他にマテガイ, シオフキガイ, アサ リなどの二枚貝類が棲息していたが, いずれも密度は低 く, 最高でも 2010 年 8 月にそれぞれ 1,150 ind. $\mathrm{m}^{-2}, 1,050$ ind. $\mathrm{m}^{-2}, 450$ ind. $\mathrm{m}^{-2}$ に止まった.

湿重量では, シオフキガイおよびアサリの成貝の個体重量 がホトトギスガイよりはるかに重いので, 両種の密度は低 かったが, 2010 年 11 月にシオフキガイは $659.9 \mathrm{gww} \mathrm{m}^{-2}$, アサリは $355.9 \mathrm{gww} \mathrm{m}^{-2}$ を記録した。ただし，ホトトギス ガイの湿重量の増加に伴ってシオフキガイの湿重量は減少 し，2011年 4 月以降はまったく採集されなかった。アサ リの場合は, 2010 年 11 月〜翌年 7 月の期間には湿重量で 126.0 1,303.1 gww m ${ }^{-2}$ の集団が，ホトトギスガイの作っ た泥状のマットの中で棲息していた。しかしながら，2010 年 8 月および 2011 年 8 月にはほとんど棲息が確認されな い状態となった（2010 年 8 月：密度 450 ind. $\mathrm{m}^{-2}$, 湿重量 $19.7 \mathrm{gWW} \mathrm{m}^{-2}, 2011$ 年 8 月: 密度 33 ind. $\mathrm{m}^{-2}$, 湿重量

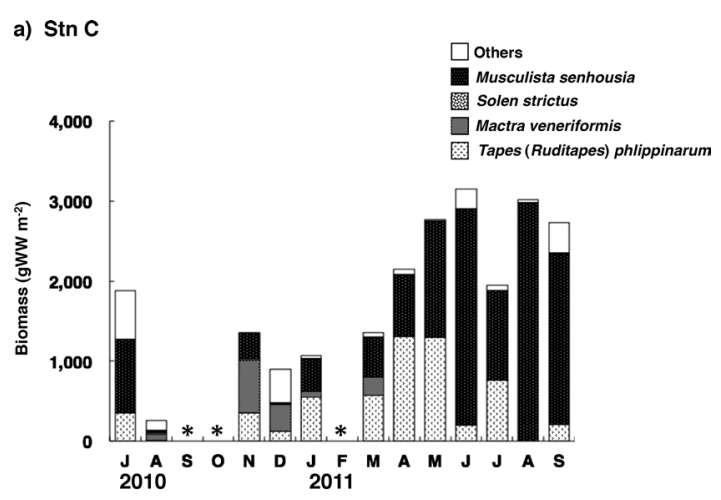

b) Experimental Stations (Stn Ex. 1 to Ex. 4)

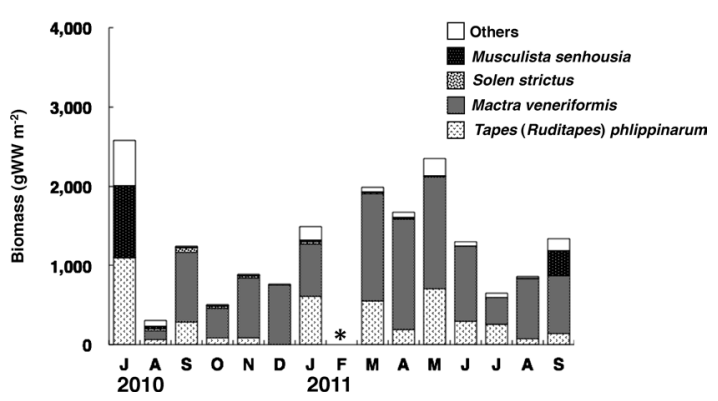

Fig. 10. Seasonal changes of biomass in wet weight of macrobenthic communities at (a) Stn C, and (b) the experimental site (the mean values of the four experimental stations, Stn Ex. 1 to Stn Ex. 4). 
$\left.0.1 \mathrm{gWW} \mathrm{m}^{-2}\right)$.これらの結果は, アサリはホトトギスガ イの泥状のマットの中でも夏季を除いては棲息可能である ことを示している. 夏季は Fig. 5(b) に示すように, 泥状 のマットの内部が強く嫌気化するので，その影響を受けて 棲息が困難であったと考えられる。

実験区（Stn Ex. 1〜Ex. 4）では，基質の擋拌直前の 2010 年 7 月には, アサリが 6,375 ind. $\mathrm{m}^{-2}$ の密度で生息 し, 湿重量も $1,097.7 \mathrm{gww} \mathrm{m}^{-2}$ に達していた。しかしなが ら, ホトトギスガイも 1,005 ind. $\mathrm{m}^{-2}$ の密度で棲息し, 湿 重量は繁殖直前の成貝が多かったので，アサリにほぼ匹敵 する $906.2 \mathrm{gww} \mathrm{m}^{-2}$ を記録した。 そのため, 基質表面はホ トトギスガイによる泥状のマットで被覆されていて, 表層 深さ $5 \mathrm{~cm}$ までの泥分は $6.6 \%$ に達していた（Fig. 7(a)). 基質の擋挥によってホトトギスガイが作った泥状のマット は破壊されて取り除かれ, 表層は泥分が 1〜2\%程度の砂 質の基質となった（Fig. 6(b), 7, 8(a)). 基質の擋找後の 2010 年 8 月には, ホトトギスガイの密度は稚貝の新規加 入によって 1,035 ind. $\mathrm{m}^{-2}$ に達したが, 湿重量はわずか 25.1 gww m $^{-2}$ にとどまった.

ここで, 実験区におけるその後の底生生物群集の動態に 関して, 次の 3 つの点が注目された。

1. Stn Cのホトトギスガイの密度と比較すると, 2010 年 8 月に新規加入した稚貝の密度は約 1/18（1,035 ind $\left.\mathrm{m}^{-2}\right)$ にとどまり, 9 月以降, 次の新加入が起 きたと考えられる 2011 年 8 月まで, ホトトギスガ イがほとんど棲息しない状態が続いた。

2. 2010 年 7 月に生息が確認されなかったシオフキガ イが 8 月には密度 1,910 ind. $\mathrm{m}^{-2}$ を記録し, 湿重量 が密度の割に少なかった $\left(103.2 \mathrm{gww} \mathrm{m}^{-2}\right)$ ことか ら，稚貝の定着が起きたと考えられた．密度がさら に増加することはなかったが, 生残した個体の成長 によっての湿重量が増加し, 2011 年 9 月まで底生 生物の種別の湿重量では高い值（318.2 1,408.2 gww $\mathrm{m}^{-2}$ ) を保った。

3. アサリはシオフキガイについで密度が高く, 2011 年 3 月〜 6 月には 45〜 160 ind. $\mathrm{m}^{-2}$ を記録し, 湿重 量では 190.0〜 711.1 gww m ${ }^{-2}$ に達した.

以上のように，基質を攪捧した実験区では，ホトトギス ガイによって作られた泥状のマットが一掃され, 底生生物 群集はシオフキガイやアサリなどの砂質の基質環境を好む 二枚貝類が優占する構成に変化し，1 年後の 2011 年 9 月 まで，再びホトトギスガイによる泥状のマットが形成する ことはなかった.

\section{考察}

ホトトギスガイは日本国内（伊藤・梶原 1981a; Yamamuro et al. 2000, 2010）だけではなく, 移入種としてオセ アニア, 北米やヨーロッパにも分布域を拡大し, 付着糸を
出して多数の個体がつながって塊となり, そこに泥が堆積 してできた泥状のマット “byssal thread mats”を形成してい ることが報告されている（オーストラリア：Willan 1987; Slack-Smith \& Brearley 1987; ニュージーランド : Creese et al. 1997; アメリカ, カリフォルニア : Crooks 1996, 1998; 地 中海 : Hoenselaar \& Hoenselaar 1989; Mistri 2002; Florio et al. 2008).このホトトギスガイによる泥状のマットが同所的 に棲息する底生生物の生息に悪影響をおよぼし, 沿岸の底 生生態系の攪乱要因として作用しているかという点につい ては，様々な議論がある。

Mistri（2004）は，ホトトギスガイの泥状のマットの中 に棲息するヨーロッパアサリ（Tapes decussatus）やアサリ の棲息に影響を与えるのかについて室内実験を行ったとこ ろ, 両種の成長や生残には影響が見られなかったことを示 した. Munari（2008）は，イタリアの地中海沿岸におい て，ホトトギスガイの泥状のマット形成によって棲息する 底生生物が豊富になったことを示した。一方, Creese et al. （1997）は, ニュージーランドの沿岸で, ホトトギスガイ のマットの中には, その外側と比較すると棲息する底生生 物が大幅に少ないことを報告した. Crooks（2001）および Kushuner (2005) は, アメリカ, カリフォルニアの海岸 で，ホトトギスガイのマット形成が基質表層に棲息する二 枚貝類 (e.g. Chione spp., Laevicardium substriatum) の生残 に大きな影響をおよぼすことを示したが, Crooks（2001） は基質に深く潜る性質を有する種（ex. Macoma nasuta）の 成長や生残にはほとんど影響がおよんでいないことを示し た。本研究の調査結果では, シオフキガイはホトトギスガ イのマットの中にはほとんど棲息しない一方で, 重機でそ のマットを破壊すると, すぐに進入して優占種として棲息 するようになった（Fig. 10）。アサリは，2010年11月〜 翌年 7 月の期間には湿重量で 126.0〜 1,303.1 gww m ${ }^{-2}$ の集 団がホトトギスガイのマットの中に棲息していたが, 2010 年 8 月および 2011 年 8 月にはほとんど棲息が確認されな い.また，この基質攪挥実験に先立って行ったホトトギス ガイのマット形成の過程を追跡した調査においても, マッ トが発達した 2009 年 9 月には, アサリの湿重量はほとん ど 0 に近い状態に減少した (Fig. 3).これらの結果は, Crooks（2001）および Kushuner（2005）が示すように，ア サリよりも基質表在性の強いシオフキガイはホトトギスガ イによるマット形成が大きな棲息の障害となり，アサリの 場合はより深く基質に潜って棲息できるので，その影響が 少ないことが示唆される. しかしながら, いずれの場合も 夏季にマットの中に生残する成貝がきわめて少なかった. ホトトギスガイのマットの内部は, この季節には極度に嫌 気化した状態に陷るので（Fig. 5(b)），アサリの成貝の生 残に大きな影響がおよぶことが指摘される。上述の外国に おける過去の研究例では, このマット内部の嫌気化の問題 が考慮されていない. 気候条件が異なるので，このような 嫌気的な状態が発生していないことも考えられる。いずれ 
にしても, 本研究の調査域である緑川河口干潟において は, アサリ漁の漁場環境を維持するためにも, 砂質干潟に 広く分布するその他の二枚貝類（シオフキガイ, マテガイ 等）の棲息環境を維持するためにも，泥状のマット形成を 伴うホトトギスガイの棲息は適度に制御された状態になけ ればならない。また，この種が独占的に砂質干潟の空間を 占有する状況は，近年までは何らかのメカニズムで抑制さ れてきたと考えられる。

ホトトギスガイは岩礁潮間帯に生息するムラサキイガイ と同じイガイ科の二枚貝類である.ムラサキイガイ (Mytilus edulis）の場合, 岩礁潮間帯における付着可能な基質空 間を巡る競争関係でもっとも強い競争力を有しており, ホ トトギスガイと同様に付着糸を出してマット状の塊となっ て岩に付着し，しばしば基質の表面を埋め尽くすほどまで に増殖する。 ところが, ムラサキイガイに対しては, 捕食 して岩礁表面の空間独占を阻むヒトデ類や巻貝類が数多く 生息している場合が多い（Dayton 1971）。ホトトギスガイ の場合にも, 同様にカ二類, 捕食性の巻貝類, 魚類, カモ 類やシギ類などの海岸に生息する鳥類などによる捕食が示 されている (Reusch 1998; Yamamuro et al. 1998; Crooks 2002). また, アマモ場の存在が, ホトトギスガイの進入 や増殖を阻害する効果を持っていることも指摘されている (Reusch 1998; Reusch \& Williams 1998).

緑川河口干潟では, 二枚貝類を捕食する巻貝としてッメ タガイやサキグロタマツメタ (Euspira fortunei) が生息し ている。しかしながら，ホトトギスガイの泥状のマットの 中からこれらの巻貝に捕食されて貝殼に穴の開いたアサリ は多数見出されるが，同様に捕食されたホトトギスガイは まったく見られず，これらの種はホトトギスガイの捕食者 としては機能していない。 また，アサリはナルトビエイや アカエイ (Dasyatis akajei) などのエイ類からも大きな捕食 圧を受けていて, 干潟の基質表面にはエイ類の捕食活動に よって作られた凹みが多数見られるが，ホトトギスガイの 泥状のマットの中にはそのような凹みは見出されない. カ モ類やシギ類などの鳥類による捕食の可能性も考えられる が, この干潟ではこれらの鳥類の生息数は少ない. また, ホトトギスガイの棲息を制限するようなアマモが密生した 場所もない. したがって, 緑川河口干潟においては, ホ卜 トギスガイの稚貝が大量に定着した場合, その増殖と泥状 のマットの形成を制御して, 干潟の基質表面の独占的利用 を制限できる捕食者は見当たらない。

緑川河口干潟において, ホトトギスガイによる基質表面 の独占的な空間利用が広範囲におよぶようになったのは近 年のことであるので, 同種の個体群サイズや分布を制御す る主要な要因として, 捕食者のような生物学的な要因以外 の要因の存在が指摘される. 本研究における重機を用いて 基質を攪拌した実験結果が示すことは, 基質表層の攪拌, つまり物理的な攪乱が，ホトトギスガイの棲息を制限する 要因の 1 つとなりうることを示している（Fig. 6〜8). ホ
トトギスガイが形成した泥状のマットに対して同様な底質 表層への物理的な攪乱をおよぼす自然現象としては, 本調 査域では台風や冬季の強い季節風によって発生する強い波 浪などが相当すると考えられる。このような基質の物理的 な攪乱によって一旦ホトトギスガイの泥状のマットが一掃 され, 砂質干潟の基質表層の泥分がわずか 1 ～$\%$ 台に減 少した砂質の基質に戻り，アサリやシオフキガイなどの懸 濁物食性の二枚貝類が優占する底生生物群集が再形成され ると，少なくとも 1 年後まではホトトギスガイの繁殖に よって稚貝の新規加入が起きても, 生残して泥状の塊を形 成するまでには至らなかった（Fig. 9(b)，10（b)）．翌年の 梅雨期の大雨の影響と考えられるが，一時的に基質の泥分 が増加しても (9.6\%, 2011 年 6 月)，ホトトギスガイがほ とんど棲息しない条件下では水中に再懸濁して，2 カ月後 には泥分は $1 \%$ 台に低下した（Fig. 8).したがって，基質 が何らかの強い物理的な攪乱を頻繁に受ける条件が存在す れば，ホトトギスガイによる泥状のマット形成が妨げられ て，基質表層を広く埋め尽くすことは妨げられると考えら れる。しかしながら，このような自然条件による基質の物 理的な攪乱作用は，年による気象条件の変化によって大き な変動が生じる. 特に, 熊本県沿岸の干潟は 2005 年以降, 本研究の期間に至るまで, 台風による環境の強い攪乱を一 度も受けていない.このような条件が続く状態でホトトギ スガイの高密度の稚貝の定着が発生すると，この種におけ る泥状のマット形成による基質表層の空間独占を阻止する ことは難しくなることが予想される，今後の研究では，砂 質干潟におけるホトトギスガイの高密度個体群と泥状の マット形成を制御する要因として, 基質の攪拌を含む物理 的な攪乱の効果に注目しながら, 砂質干潟におけるホト卜 ギスガイとアサリをはじめとする二枚貝類の個体群の動態 に関する相互作用についてさらに研究を進めていきたい。

謝辞 : 基質サンプルの粒度組成について詳細な解析のために鹿 児島大学総合博物館所有のレーザー回折式粒度分布測定装置を用 いた．館長の大木公彦教授には同装置の使用を許可していただ き, ならびに粒度分析の結果の検討に助言をいただいた. 文末な がら厚くお礼申し上げる.

\section{引用文献}

Creese, R., S. Hooker, S. De Luca and Y. Wharton 1997. Ecology and environmental impact of Musculista senhousia (Mollusca: Bivalvia: Mytilidae) in Tamaki Estuary, Auckland, New Zealand. New Zealand Journal of Marine and Freshwater Research, 31: 225-236.

Crooks, J. A. 1996. The population ecology of an exotic mussel, Musculista senhousia, in a southern California bay. Estuaries, 19: 42-50.

Crooks, J. A. 1998. Habitat alteration and community-level effects of an exotic mussel, Musculista senhousia. Marine Ecology Progress Series, 62: $137-152$.

Crooks, J. A. 2001. Assessing invader roles within changing ecosystems: historical and experimental perspectives on an exotic mussel in an urbanized lagoon. Biological Invasions, 3: 23-36.

Crooks, J. A. 2002. Predators of the invasive mussel Musculista senhou- 
sia (Mollusca: Mytilidae). Pacific Science, 56: 49-56.

Dayton, P. K. 1971. Composition disturbance and community organization. The provision and consequent utilization of space. Ecological Monographs, 45: 137-59.

Florio, M., P. Breber, T. Scirocco, A. Specchiulli, L. Cilenti and L. Lumare. 2008. Exotic species in Lesina and Varano lakes new guest in lesina and varano lakes: Gargano National Park (Italy). Transitional Waters Bulletin, 2: 69-79.

藤森常生 - 堤 泰博 - 岩村征三郎 1983. 畠口地先アサリへい死調 査（その 2). 昭 57 年度熊本県のり研究所事業報告書, pp. 201205.

Hoenselaar, H. J. and J. Hoenselaar 1989. Musculista senhousia (Benson in Cantor, 1842) in the western Mediterranean (Bivalvia, Mytilidae). Basteria, 53: 73-76.

池末 弥 1980. 有明海のエビ・カニ・貝類. 月刊海洋, 12: 97104.

伊藤信夫・梶原 武 1981a. 横須賀港におけるホトトギスガイの 生態-I 分布, 個体数変動および生息域底質の全硫化物. 付 着生物研究, 3: 37-42.

伊藤信夫・梶原 武 1981b. 横須賀港におけるホトトギスガイの 生態一II 足糸および足糸マットの構造. 付着生物研究, 3: 4346.

梶山 実・藤森常生・野尻節郎 1983. 畠口地先アサリへい死調査 (その 1). 昭和 57 年度熊本県のり研究所事業報告書, pp. 197200.

柿野 純 2000. アサリの生息条件と大量発生. 海洋と生物, 127: $143-154$.

環境庁 1994. 第 4 回自然環境保全基礎調査報告書（干潟, 藻場, サンゴ礁調査) 第 1 巻 干潟. 環境庁自然保護局, $291 \mathrm{pp}$.

環境省 2006. 委員会報告（平成 18 年 12 月 21 日), 環境省有明 海・八代海総合調査評価委員会, $80 \mathrm{pp}$.

菊池泰二 2000. 干潟浅海系の保全の意義. 佐藤正典(編), 有明海 の生きものたち, 海游舎, 東京, pp. 306-317.

Kushuner, R. B. 2005. The effects of the introduced Asian mussel Musculista senhousia on native bivalve growth and survival in southern California. Master thesis in Biology, San Diego State University, 32 pp. (http://coe.sdsu.edu/ste/faculty/cmason/documents/vita july_2011.pdf)

MacIntyre, H. L. and J. J. Cullen 1996. Primary production by suspended and benthic microalgae in a turbid estuary: time-scales of variability in San Antonio Bay, Texas. Marine Ecology Progress Series, 145: 245-268.

松川康夫・張 成年・片山知史・神尾光一郎 2008. 我が国のアサ リ漁獲量激減の要因について. 日本水産学会誌, 74: 137-143.

Mistri M. 2002. Ecological characteristics of the invasive asian date mussel, Musculista senhousia, in the Sacca di Goro (Adriatic Sea, Ita1y). Estuaries, 25: 431-440.

Mistri M. 2004. Effect of Musculista senhousia mats on clam mortality and growth: much ado about nothing? Aquaculture, 241: 207-218.

門谷 茂 2000. 瀬戸内海の現状と干潟域における物質循環. 海洋 と生物, 129: 323-331.

Montani, S., P. Magni and N. Abe 2003. Seasonal and interannual patterns of intertidal microphytobenthos in combination with laboratory and areal production estimates. Marine Ecology Progress Series, 248: 79-91.

Munari C. 2008. Effects of the exotic invader Musculista senhousia on benthic communities of two Mediterranean lagoons. Hydrobiologia, 611: 29-43.

中原康友・那須博史 2002. 主要産地からの報告一有明海熊本県沿 岸. 日本ベントス学会誌, 57: 139-144.

Reusch, T. B. H. 1998. Native predators contribute to invasion resistance to the non-indigenous bivalve Musculista senhousia in southern California, USA. Marine Ecology Progress Series, 170: 159-168.

Reusch, T. B. H. and S. L. Williams. 1998. Variable responses of native eelgrass Zostera marina to a non-indigenous bivalve Musculista senhousia. Oecologia, 113: 428-441.

Slack-Smith, S. M. and A. Brearley 1987. Musculista senhousia (Benson 1842): a mussel recently introduced into the Swan River Estuary, Western Australia. Records of The Western Australian Museum, 13: 225-230.

菅野 徹 1981. 有明海自然・生物・観察ガイド. 東海大学出版 会, 泰野, $194 \mathrm{pp}$.

堤 裕昭 2005. 有明海に面する熊本県の干潟で起きたアサリ漁業 の著しい衰退とその原因となる環境変化. 応用生態工学, 8 : 83-102.

Tsutsumi, H. 2006. Review: Critical events in the Ariake Bay ecosystem: clam population collapse, red tides, and hypoxic bottom water. Plankton and Benthos Research, 1: 3-25.

堤 裕昭・石澤紅子・冨重美穂・森山みどり・坂元香織・門谷 茂 2002. 緑川河口干潟における覆砂後のアサリ（Ruditapes philippinarum）の個体群動態. 日本ベントス学会誌, 57: 177187.

堤 裕昭 - 竹口知江 - 丸山 渉・中原康智 2000. アサリの生産量 が激減した後の緑川河口干潟に生息する底生生物群集の季節変 化. 日本ベントス学会誌, 55: 1-8.

Underwood, G. J. C. and J. Kromkamp 1999. Primary production by phytoplankton and microphytobenthos in estuaries. Advances in Ecological Research, 29: 93-153.

Willan, R. C. 1987. The mussel Musculista senhousia in Australasia; another aggressive alien highlights the need for quarantine at ports. Bulletin of Marine Science, 41: 475-489.

Yamaguchi, H., H. Tsutsumi, M. Tsukuda, S. Nagata, C. Kimura, M. Yoshioka, S. Shibanuma and S.Montani 2004. Utilization of photosynthetically produced organic particles by dense patches of suspension feeding bivalves on the sand flat of Midori River Estuary, Kyushu, Japan. Benthos Research, 59: 67-77.

Yamamuro, M., J. Hiratsuka and Y. Ishitobi 2000. Seasonal change in a filter-feeding bivalve Musculista senhousia population of a eutrophic estuarine lagoon. Journal of Marine Systems, 26: 117-126.

Yamamuro, M., J. Hiratsuka and Y. Ishitobi 2010. What prevents Musculista senhousia from constructing byssal thread mats in estuarine environments? A case study focusing on Lake Shinji and nearby estuarine waters. Landscape and Ecological Engineering, 6: 23-28.

Yamamuro, M., N. Oka and J. Hiratsuka. 1998. Predation by diving ducks on the biofouling mussel Musculista senhousia in a eutrophic estuarine lagoon. Marine Ecology Progress Series, 174: 101-106. 